\title{
Identity is a Joking Matter: Intergroup Humor in Bosnia
}

SRDJAN VUCETIC

Why do people tell jokes and where do they come from? That jokes are ubiquitous social phenomena can be appreciated by anyone with even the slightest interest in advertising, entertainment, or popular culture in general. In Bosnia, jokes are everywhere, and Bosnian ways of lampooning of self and others are legendary, at least as far as the exYugoslav cultural space goes. In this essay, I argue that jokes are often about identity, and that identity is often about jokes. I look at the representations of three in-group identities in Bosnian humor - ethnic, gender and regional - and I discuss several propositions about the above questions. I conclude that social groups - able-bodied males, heterosexuals, Bosniaks, Herzegovinians - are discursively represented and constituted through jokes, and that joke-tellers, re-tellers, and listeners all bear responsibility for the consequences of this process.

Searching for an answer to the "continuing question 'what's it like there?'" a traveler to post-war Sarajevo starts with what he calls the "selfdeprecating" Bosnian jokes:[1]

In retelling these jokes, I also eventually managed to convince myself that there was logic behind my strategem: where do such jokes come from, after all? why do people tell them? and wasn't the collective voice behind them more direct, more authentic, than anything that I myself might say? At one point, I even thought about compiling a Sarajevo Joke Book, a sort of exercise in contemporary folklore. One Bosnian who heard this idea from me commented, 'Sure, everyone who comes here wants to do that.' (Hicks 2002)

The Sarajevo Joke Book would be a hefty volume. As far as regional and ethnic stereotyping goes in the former Yugoslavia, Bosnians are seen as simple, forthright and fun-loving and, as such, are taken to be great raconteurs and connoisseurs of jokes. 
A Montenegrin, a Serb and a Bosnian come to the railway station. Once they arrive, they realize that the train is leaving. They start running: the Montengrin gives up immediately, the Serb shortly afterwards, only the Bosnian manages to hop on the train and leave. The Montenegrin and the Serb return looking somewhat discontented. A person who observed it all asks them: "How is it that the Bosnian got on, and you didn't?" - "Oh, that guy?! The fool was only supposed to take us to the station."

As I will show below, anthropologists have long noted, for example, that some cultures deploy jokes to define and maintain certain kinship and ethnic relationships. In the above joke, it is clear that Serbs, Bosnians, and Montenegrins are socially related, but separate. But why is the Bosnian dumber than others? As a Bosnian, I have retold this joke many times. Why, then, do I tell a joke in which my people turn out to be dumb?

In this paper, I will look at contemporary jokes in and around Bosnia and at the questions raised by Hicks: 1) why people tell jokes and 2) where they come from. In attempting to answer the first question, I will link these questions to the literature dealing with identity politics and will explore various patterns of intergroup humor in Bosnia. As for the second question, I will use selected illustrations to discuss several hypothesis-like propositions on the genesis of jokes in this country.

WHY DO PEOPLE TELL JOKES?

It can be said that intergroup humor refers to relationships between ingroup and out-groups, as situated within a structured network of broader social relations. A reflection by Alan Dundes may be telling:

\begin{abstract}
As a folklorist, I have come to believe that no piece of folklore continues to be transmitted unless it means something - even if neither the speaker nor the audience can articulate what the meaning might be. In fact, it usually is essential that the joke's meaning not be crystal clear. If people knew what they were communicating when they told jokes, the jokes would cease to be effective as socially sanctioned outlets for expressing taboo ideas and subjects. Where there is anxiety, there will be jokes to express that anxiety (1987: vii; emphasis in the original)
\end{abstract}

I would venture further and say that intergroup humor is essentially about identities: jokes serve to alleviate some sort of ontological anxiety, a fear of the unknown and uncontrollable. According to Giddens (1991: 183), ontological security is the security of being and the maintenance of a "known" and "controllable" identity. Using the same language and looking the same as an "other" can cause a loss of a sense of place and 
identity and result in a withdrawal from certain experiences. Generally speaking, jokes can be deployed as a tool to alleviate this loss of a sense of place and identity.

There are, no doubt, a myriad of ways to talk about identity. In this account, I am interested in theories that look at, first, the psychological link between individuals and the social groups to which they belong and, second, at actor behavior. Psychological process theories indicate the values that individual actors espouse are related to their in-group identities and, in turn, that these values are linked with the likely effectiveness of different strategies the actors choose to pursue.[2] One's self-conception can thus be seen as an amalgam of the characteristics of various social groups to which one belongs - gender, age, racial, ethnic, religious, political, administrative, etc. In other words, individuals with similar social identities are likely to have similar perceptions, values, beliefs and interests.

Furthermore, social identity also provides a blueprint for action as the "we"-feeling induces loyalty and duty to the group. For example, the idea and practice of citizenship (or nationality) is the legal representation of a person's relationship to the rights, privileges, duties, and responsibilities of the nation-state. It can therefore be said that in-group identities prescribe the ways of thinking about the likely effectiveness of different strategies the actors have at their disposal and thus have important behavioural implications.[3] In this paper, I am primarily interested in three in-group identities - ethnic, gender and regional (center vs. periphery) - and in the ways in which these identities unravel in and around Bosnia.

Jokes are ubiquitous social phenomena. Many jokes can be regarded as narratives that provide a way of locating both the narrator within his/her group and that group's relationship to other groups; that is, jokes serve to situate the self within a particular social and political world. The deployment of jokes constitutes the attributes of certain social groups as "typical" and, according to Dundes, "may be more responsible for the first group's attitudes about the second than any other single factor" (1987: 96). Ethnic jokes, for example, not only "describe" what is typically American, Jewish or Bosnian, they also inscribe or constitute these groups as such. 
Stereotype-rich intergroup jokes can then be seen as "cultural signifiers" (Duara 1996: 165) or even invented traditions, which implies that they act to "socialize or inculcate beliefs, values, or behaviors" (Hobsbawm 1983: 9). Because jokes are passed from one generation to the next, they foster a sense of "we-feeling" across time as well as space. When we joke about, say, Scots and Newfoundlanders, we pretend to be referring to an objective thing. But in joking, we socially construct and sustain relationships within those groups as well as between those groups and others. According to Apte, who builds on Durkheim's concept of collective representations, jokes "help define and redefine the boundaries of socially differentiated groups" and demarcating "us" from "them" (1985: 55). And with the construction of difference comes the construction of the "other", and hence, of hierarchy and exclusion (Berger and Luckmann 1996, Connolly 2002).

Intergroup humor divides the social and political world into ingroups and out-groups, which by itself is an act deeply embedded in power relations (gender, centre vs. periphery, class). Stereotypes (e.g. Scots are stingy, Newfoundlanders are stupid, etc.) serve as boundarybuilders and, as such, are an important basis for the construction of social identities and corresponding social relations. Of course, there are other narratives responsible for proliferating social stereotypes, such as newspapers, school textbooks, talk shows, commercials, and every-day conversations. The point is that by disseminating stereotypes jokes "contribute materially to the formation and perpetration of deep-seated prejudices" (Dundes 1987: 115). In this way, jokes also serve certain interests more than others.

Let me mention three important caveats. First, I am interested in the discursive effect of jokes, not in the joke-teller's intent per se. Dundes proposes that "the vast majority of people [who] transmit and enjoy [...] jokes seems to have little idea of the possible meaning behind them" (1987: vii). And if it is true that most people tell jokes without actually reflecting on them and/or without believing in what they imply, it is pointless to search for motives and purposes (Davies 1990: 3, 2002: 13).

I would imagine that behavioralists and rational choice theorists would have little interest in intergroup humor as this is an activity which is seemingly not goal-oriented and which does not fit into the usual account of motivation, which almost exclusively looks at drive-reduction and need-motivation. Telling, retelling and listening to jokes can thus 
more fruitfully be located with the logic of habit, custom or everyday, which arguably accounts for the greatest part of social life (Hopf 2002: 1316). But my paper aims to be explorative, not exhaustive: any recovery of identities and social relations through intergroup humor is a tremendous empirical challenge, which is, again, obviously not met in this paper.

Jokes that are examined in experimental situations are almost never representative of the evolving social and political world and the data set outside the laboratory is unwieldy as jokes generally exist in verbal form. A major repository of jokes for this paper is the Internet, especially http://vicevi.net - a Bosnian website exclusively dedicated to exYugoslav humor which, at the time of the writing (July 2003), contained around 6,000 jokes. But because the Internet is a notoriously unreliable source of "evidence" - in the social scientific sense at least - jokes presented in this paper come from countless 'informal interviews' with Bosnians and other ex-Yugoslavs, both in the homelands and the diasporas. In other words, the database of jokes collected off the Internet is secondary to that gathered in my "fieldwork." [4] Translations from Bosnian/Croatian/Serbian are mine unless otherwise noted.

Second, Hicks rightfully warns that jokes "don't speak for themselves, however much we may be predisposed to let them do so." What the author means to imply is that an ontological self-cleansing is utterly impossible: any ethnographer will change the intersubjective and contextual evidence no matter how hard she tries to "let it speak for itself." Even if a collection of jokes contains no analysis - as is the case in many popular anthologies of humor - the meaning of evidence is changed, say, in the way a table of contents is set up.

Third, most jokes, especially those of the ethnic, regional or gendered type, are offensive and repugnant. Like telling and retelling of jokes, this reflection on intergroup humor disseminates and popularizes certain stereotypes and identities, and, of course, reifies given social relations. Having said that, I believe that one can effectively combat closure and essentialization with the use of "strategic essentialism" - acting as if identities and social relations were fixed and homogeneous with the aim of accomplishing interim intellectual and political goals, which include, among others, the problematization of reification (Spivak 1990).[5]

Allow three brief definitional notes. First, Bosnia is a complex case to study identity politics because, among other things, all three constituent 
ethno-national groups are self-perceived minorities (Bose 2002: 259). But while Serbs and Croats are widely considered to be "unproblematic" ethnic (in Bosnia) and national groups (i.e. they have their own nationstates), Bosnian Muslims or Bosniaks have often been denied the status of a distinct cultural, ethnic, national and linguistic community, in that chronological order.[6]

Second, ethnic identities in Bosnia are extremely situational and, to use Prasenjit Duara's term, "chameleon-like" (1996: 164). Speaking in terms of ethnic identity, the elasticity, multiplicity, and overlap of identities were/(are?) especially salient among the Bosniaks. It was thus possible for a famous Bosniak poet to begin life as a "Serb," later ethnically "convert" to a "Bosniak," but to end up as a "Croat" (Ramet 1996: 125).

Before the war, at least in the urban areas where the rate of interethnic marriage was high, it was common for people of different ethnic and religious backgrounds to identify themselves as "Bosnian" (as it was fairly common for oneself to identify as "Yugoslav"). During the war in Bosnia, the Western media identified Bosnian Muslims as simply "Bosnians," which ostensibly meant non-Serb or non-Croat. I, for one, am not sure that the identifier "Bosnian" has now more decisively been replaced with the three mutually exclusive identifiers - Bosniak, Bosnian Croat and Bosnian Serb (like the word "Bosniak," the terms "Bosnian Serbs" or "Bosnian Croats" were arguably invented in the 1990s).

The general term "Bosnian" continues to be used not only as an adjective for Bosnia and Herzegovina, but also, importantly, as a term of choice for ethnic and national identity of those Bosnian citizens who do not want, for various reasons, to call themselves Bosniak, Croat or Serb. Some "still" claim that there is one Bosnian nation, divided by different religions, as is the case in, e.g., Albania. Others, like those with ethnically mixed background, often employ multiple ethno-national identities, even if these, in turn, may be institutionalized in opposition to each other (e.g. consider the debates on dual citizenship in Bosnia and elsewhere).

In Bosnia, despite coercive and systematic attempts to irrevocably "harden" the boundaries between ethnic communities in Bosnia, a "confusion of identities" still exists (see, e.g., various contributions to Jones and Lovrenović 2001). Of course, even such identification is context-bound and, as always, depends on a host of other factors (Duara 
1996: 165). All of these illustrations imply that identities are not fixed things but ongoing and malleable social constructions.

As far as jokes and joking are concerned, many non-Bosniak Bosnians continue to identify themselves with Mujo, Suljo and Fata - the "stock characters, the fools of Bosnian comedy" (Hicks 2002) - who bear clear Bosniak names. When told in Serbia and Croatia, for example, jokes about "Bosnians" are in fact often directed at Bosnian Serbs and Bosnian Croats. So for all these reasons, I am partial to use the term Bosnian jokes, even when I refer to the stories involving nominally "Bosniak" characters.

Third, the name Bosnia and Herzegovina itself demarcates two regional identities: Bosnian and Hercegovinian. And while they are by no means differentiated along the lines of ethnicity, strong regional tensions exist (and in fact within each individual ethnic community), which is revealed in humor as well (Ramet 1996: 123).

\section{JOKING RELATIONSHIPS AS AN ANALYTICAL CA T EGORY}

Following Apte (1985), joking relationships can be defined as social relations which constitute social identities. Brandt (1948), for instance, found that joking relationships provide external controls for the sexual and aggressive urges that are most likely to seek expression in the violation of social taboos. Joking relationships are then functional inasmuch as they channel these taboo urges in acceptable ways. But as Apte notes, it is the content, not the possible functionality, of jokes that poses more challenging research puzzles. In the following, ethnic and/or regional identities in the former Yugoslavia are constructed through socalled multi-group jokes (Dundes 1987: 108):[7]

A Slovene, a Bosnian and a Montenegrin run a 100-meter race. The Slovene wins. Why? The Montenegrin gave up, and the Bosnian lost his way.

A Bosnian interviews for a job in Slovenia. "Where are you from?" asks the employer. "From Bosnia!" "Oh, I know," says the Slovene, "you Bosnians are known to be lazy." "Oh no, sir," responds the Bosnian, "those are the Montenegrins. We Bosnians are stupid!" 
Why did the Montengrin become so lazy? Because the Bosnian once said to him: "Let me explain..."

A Bosnian and a Slovene sit in a train and decide to eat the two apples they brought along. One apple is bigger than the other. The Bosnian takes the bigger apple. The Slovene goes: "Shame on you, don't you have any manners?" The Bosnian is puzzled: "What do you mean, which one would you take if you were first?" "The smaller one, of course," says the Slovene. The Bosnian, angered: "But I gave you the smaller one, didn't I?"

These examples are indicative of a larger opus of joking relationships in the former Yugoslavia. According to Apte, joking relationships reveal that, among other things, the narrator (non-Bosnian) and object of the joke (Bosnian) are socially related in a relatively permanent way. This is an obvious point as the histories of these ethno-national communities are highly intermingled. But they also reveal the asymmetrical nature of joking relationships: the Slovenes are naïve and polite, Montenegrins are lazy, and Bosnians are stupid. Of course, there are cohorts of jokes that reinforce each of these stereotypes individually. Here is a selection about the Bosnians:

"I think, therefore I am," says a Bosnian and disappears without a trace.

In Bosnia, an intellectual is the person who can read without moving his lips.

A son come back from his very first day of school: "Daddy, you won't believe what happened today. We had math today and it turns out my classmates could only count to 20, but I counted to 100!” The father replies: “Bravo, son! That is because you are Bosnian!"

The next day, the son is even more excited: "Daddy, another incredible thing happened in school. In English class, my classmates knew only 10 letters of the alphabet, I knew all 26!" The dad applauds: “Bravo, son! That is because you are Bosnian!"

On the third day, the son comes back absolutely overjoyed: "Daddy, we had physical education today and in the locker room we boys looked at our dicks. My friends have such small dicks compared to mine! Is it because I am Bosnian?"

"No," responds the father, "that is because you are eighteen."

These jokes, I posit, are representative of a larger sample of ethnic jokes in the former Yugoslavia. The vicevi.net website, for example, has a section dedicated to the multi-group jokes, where in an absolute majority (about $80 \%$ ) of ethnic jokes that involve them, it is Bosnians who come out the worst. Another large section (650 jokes at the time of writing) deals with the popular Suljo, Mujo and Fata jokes. 
All three names are clear social markers as they unambiguously denote Bosnian Muslims: Mujo stands for Mustafa or Muhamed; Suljo for Sulejman; and Fata, usually Mujo's wife, for Fatima. Sometimes, the names Huso and Haso (short for Husein or Husref and Hasan or Hasib, respectively) are also used. In addition to being portrayed as stupid, Bosnians come out as sexually promiscuous, omnisexual, and alcoholic:

A Montenegrin married Fata. The first night they go to bed and the Montengrin goes: "If a Montenegrin was here, she would now take off my clothes." Fata, a little upset, takes off his clothes. The Montenegrin, again: "If a Montenegrin was here, she would now help me get it on." Fata, annoyed, helps him again. The Montenegrin, finally: "If a Montenegrin was here, she would now get on top." Fata, completely exasperated, gets up and goes to the door. The Montenegrin, surprised: "Where are you going?" Fata: “What do you mean, where I am going? If Mujo was here, he would fuck both me and you and would go outside looking for more!!!"

Fata is doing laundry in a pond and is bent over. Two young boys see her and decide to take advantage of the situation. They sneak up on her, 'doggy-style' her and run away. Fata seems undisturbed and continues with her work. Mujo happens to see that from the house, so he too decides to take advantage of the situation. He sneaks up on Fata, 'doggy-styles' her and runs away. Again, Fata appears unperturbed and continues to be concentrated on her laundry. A bear sitting on a nearby tree sees both the boys and Mujo take advantage of the situation so he too decided to the same. When he finished, Fata says, still while doing laundry in a bent-over position, "Hey you... you in the fur coat, leave me your phone number."

"Mujo, haven't you heard, the male gorilla in the Sarajevo Zoo is seriously ill and the female gorilla is going crazy without sex. They are now looking for somebody to replace the male gorilla and they are willing to pay up to 5,000 marks!" says Suljo. Mujo responds, “Oh yes, I heard, but where will I find 5,000 marks?"

A Bosnian television is shooting a documentary intended for children. In this episode, they visit Mujo working on his farm. "How do you start your day?" asks the reporter. Mujo responds: “Well, when I get up, I drink one shot of rakija [plum brandy]." "Wait a second, this is a story for children! We want you to say something that's good for them. For example, when I get up, I read a book." "OK, I get it," says Mujo, "When I get up, I read a book. Then when I go to work on the farm, I read another one. Then when I get back from the work, I read two books. A little later, Suljo and I go to the library and there we read five to six books. When the librarian kicks us out before closing, we go to Haso, he owns a publishing house."

Here several stereotypes are perpetuated: sexual division of labour (the gendered nature of jokes will be examined below), sexual promiscuity, 
bestiality, bisexuality and extreme (and rural) drinking habits. All of these themes point to the backwardness of Bosnians.

According to Davies (1990: 40, 2002: 8), jokes in which the object or the butt of the joke turns out to be primitive or stupid are the most common type. Jokes such as these lampoon the follies and failures in "others" not only in order to differentiate them from the self (i.e. the narrator) but also to impart values that the self uses to define his/her own group (1990: 7). The butt of the joke is thus habitually perceived as provincial, rural, backward, pre-modern, that is in contrast to the narrator who is central, urban, progressive and modern (1990: 82-3).

While my fieldwork as well as my exploration of the Internet data sets containing ex-Yugoslav jokes is by no means exhaustive, it can be said that the joking relationships among ex-Yugoslav ethnic communities show one significant pattern: Bosnians are the usual laughingstock.[8]

These joking relationships, on the surface, demonstrate a superiority vs. inferiority pattern that fits the dominant discursive formations. Building on the work of Said, and in an effort probably parallel to that of Wolff and Todorova, Bakić-Hayden introduces the notion of 'nesting orientalisms,' which can elucidate the ways in which ethnic identities in the former Yugoslavia are constructed:

The phenomenon of nesting orientalisms is evident in the former Yugoslavia and its successor states where the designation of 'other' has been appropriated and manipulated by those who have themselves been designated as such in orientalist discourse. Thus, while Europe as a whole has disparaged not only the orient "proper" but also the parts of Europe that were under oriental Ottoman rule, Yugoslavs who reside in areas that were formerly ruled by the Ottoman Empire, hence 'improper.' Within the latter area, eastern Orthodox peoples perceive themselves as more European than those who assumed identities of European Muslims and who further distinguish themselves from the ultimate orientals, non-Europeans (1995: 992).

Bakić-Hayden goes on to document instances of such 'nesting' in the statements made by state officials and intellectuals and the media, including outsider accounts, such as the New York Times.[9] In the most common 'nesting' scheme, Slovenes and Croats come out on top as most "European," Serbs are somewhere in the middle, and the Bosnian Muslims are most "Oriental." This phenomenon seems to be reflected in the above joking relationships.[10] 
Montenegrin jokes show that the 'nesting' scheme is imperfect: in addition to being lazy, Montengrins are also seen as uncouth and backward. Because the largely Orthodox Montenegro is the least modernized of ex-Yugoslav republics, it is possible that Montenegro is in fact more "Oriental" than Bosnia or, at least, that the joking relationship between Montenegrins and Bosnians is symmetrical (Davies 1990). But the ultimate "Orientals" in the former Yugoslavia like elsewhere in Eastern Europe are, I believe, the members of the Roma/Sinti community, belittlingly known as “Gypsies."[11]

\section{WHEREIN LIES THE SELF-PARODY?}

Bosnian jokes are often seen as self-deprecating (e.g. Hicks). In other words, it is Bosnians who imagine humorous stories in which they themselves look dumb and/or primitive. The Suljo, Mujo and Fata jokes are a Bosnian trademark:

A Frenchman, a German and Mujo are talking about their wives. The Frenchman: "My wife is like an antelope, she walks without touching the ground. She practically flows around me." The German: "My wife is like a butterfly: one second she is over here, the next she is over there. She practically flies around me." Mujo, after several of moments of thought: "Now that I think about it, my Fata isn't human either [ni ona moja Fata nije insan]".

The US and Bosnia play a waterpolo match. The US team leads 10:0 and has just scored the tenth goal. The Bosnian team has the ball. The Bosnian coach yells: "Mujo, pass the ball to Suljo!" Mujo does not heed the coach but continues to swim in the direction of the US goalie. The coach, "Mujo, give the ball to Suljo now!!!" Mujo continues into the opponent's half. The coach, furious: “Give him the ball, idiot!" Mujo doesn't listen, goes all the way and scores the first goal for Bosnia. Ecstatic, he turns to the coach to celebrate. The coach looks at him with a very sombre face: "I told you to pass the ball to Suljo. The man drowned in the pool."

In these two jokes, Bosnians are considered incapable of abstract thought and swimming (i.e. they need the waterpolo ball to keep afloat), which again underlines the stereotype of a backward community. According to the unwritten common wisdom on ex-Yugoslav humor, it is Bosnians themselves who create these jokes, just as Scots, Jews, Newfoundlanders and Australians are widely believed to have produced the jokes about themselves in which they are portrayed as stupid (Davies 2002). 
Studies in intergroup humor involving majority-minority joking relationships have found that minorities generally tell more jokes, particularly self-deprecating jokes (Nevo 1984: 183). One may be tempted to suggest, following Dundes (1987: 103), that here we have a case where "a group has come to accept the stereotype of itself as defined by outgroups." For example, African-American children are conditioned to think that "black" is an evil color (ibid.), which was, in fact, proven in experiments where young black girls, when given a choice between a white-skinned and dark-skinned Barbie dolls, overwhelmingly chose the former. Joking relationships, I submit, are much more complex. Let me offer five alternative propositions on Bosnian self-deprecating jokes.

Proposition 1. If ethnic jokes serve to create, as Davies (1990: 7) claims, "a sudden vicarious superiority felt by those who devise, tell or share a joke," then it is every group except Bosnians that feels the need to feel this superiority. Bosnians may, then, be the most secure about themselves, so to speak. Furthermore, some jokes reveal that, in addition to the usual play on stupidity, there is a strong element of "the-joke-ison-you" irony. While playing dumb, Bosnian attempt to, in fact, come out on top.

Perhaps following historical and diasporic experiences, Bosnians often differentiate themselves from Americans and Europeans, especially Germans.

Mujo is relaxing in a sauna in Germany. A cell phone goes off. Mujo sees a German reach beneath his towel, get the cell phone and talk about important business. The same happens, seemingly, with every other German in the sauna: everyone seems to have a cell phone and some important business to run. After a while, only Mujo has not had a phone conversation, and the Germans begin to look at him suspiciously. Mujo, uneasy about being perceived as an outsider, excuses himself and goes to the bathroom. There, he stuffs his butt with toilet paper. Upon return to the sauna, one Germans remarks: "Sir, there seems to be some paper sticking out of your ass." "Ah, thank you," Mujo responds, "that must be my fax!"

Here, there are two interpretations. Apart from the obvious and usual interpretation where the Bosnian comes out stupid, it can also be said that it is the Germans who are lampooned for trying to be overly industrious and efficient. The joke, in other words, is about a clash of values. So the Bosnian-German joking relationship, if any such thing can be said to exist, is less related to inferiority/superiority than to a struggle for respect and the recognition that values between communities differ. This example also demonstrates that is not easy to classify jokes into two 
main categories: 1) those where the butt of the joke is considered stupid, and 2) those where the butt turns out to be shrewd (Davies 1990: 40, 82, 102; 2002: 8). Both types of jokes may be at play above.

Proposition 2. It all depends on who tells the joke. If one person tells a joke, others may be exceptionally funny, while if another does, it may be disgusting, terrible and dangerous. Here is how it may work. When a Bosniak tells a joke about Mujo and Suljo to another Bosnian, it may be seen as an homage of sorts to Bosnian beliefs, values, and behaviors. When the same joke is told by a Serb or a Croat, however, the occasion may be seen as an invitation to an exchange of ethnic slurs or worse. Similarly, just because derogatory words are more or less freely used by the members of the in-group, this is no invitation to the out-groups to also use them.

It all depends who uses the word. Afro-Americans may use the word "Nigger" or "Nigga" profusely, but any such use of the word by whites is corrected or otherwise sanctioned. Similarly, Bosnians will tell war jokes (below) and will laugh at them but will generally not tolerate it when Serbs tell the same jokes.

To use a functional argument, one can argue that an element of selfmockery can also be used in affirming ethnic and racial identity - telling and retelling a joke is a chance to share in a tradition that unites otherwise distinct individuals. It can also be argued, along Davies's lines, that by profusely using self-depreciation, Bosnians, like Jews, Scots, Newfoundlanders and Australians, have "a marked capacity for selfreflection about their own identity" (2002: 3). The identity of Bosnians has been written and re-written through jokes by Bosnians themselves.

Thus, Bosnian jokes can be seen as stories the Bosnians tell about themselves but perhaps also to themselves. Their self-mocking style emerges perhaps from a preoccupation with physical and social security, which is discussed in a non-threatening, humorous vein. Defining and recounting these insecurities demonstrates specialized knowledge and reinforces traditions. In fact, the Mujo, Suljo, and Fata jokes clearly belong to a much broader ambit of Bosnian jokes.

In Bosnia, among Bosniaks in particular, there is a longer tradition of the Nusrudin-hodža jokes - tales poking fun at stupidity, every-day embarrassments as well as religious ignorance - which originated in the Ottoman times, probably as Bosnian adaptations of Turkish and Arab 
jokes. As such, the Nusrudin-hodža jokes no doubt contributed to the construction of a distinct religious and later ethnic, national, and linguistic community.[12] The Mujo, Suljo, and Fata jokes can perhaps be regarded in a similar fashion.

Proposition 3. It can be argued that Bosnian jokes are really about intergroup relationships within Bosnia, or within the Bosniak ethnic group. Thus, when the Bosniaks tell Suljo, Mujo and Fata jokes, the narrators perhaps do not laugh at themselves but at a specific social group (i.e. lower classes, peasants) within the Bosniak ethnic group from which they seek to distance themselves. Davies, in his comparative study of self-mocking humor, finds: "Self-mocking jokes often refer far more strongly to another section of one's nation than to one's own and from the point of view of the immediate teller and listener can always be perceived or represented as about someone else" (2002: 5).

One can therefore argue that it is class or regional, not ethnic and national, identities that are here being delineated. Here jokes serve to divide an otherwise 'unified' ethnic and national identity. That class may be an important factor in humor can be gauged from looking at joketelling as a speech performance: the impact of a joke is often both intellectual and auditory. The telling of jokes requires linguistic competence (Davies 1990, 2002). Jokes about lower classes may involve different vocabulary and intonation. The same can be said by intramural regional and gender differences.[13] The gendered aspect of Bosnian jokes is especially pronounced.

It is clear even from the selection of jokes in this paper that certain identities are highlighted and endorsed more than others - particularly that of the able-bodied, heterosexual male. Women, as some of the examples above suggest, are portrayed as inferior. Here are two more examples:

Mujo sits at the bar and orders a beer from the bartender Haso. "There you go," says Haso, "that will be 10 cents." Mujo, surprised: "10 cents!!! OK, then give me a Jack Daniels." Haso: "Jack is a little expensive: 30 cents, please." Mujo, surprised even more: "30 cents!!! Where is the owner of this establishment?" Haso: "Upstairs, with my wife." Mujo: "What is he doing with your wife, man?" Haso: "The same thing I am doing with his business."

Fata asks Mujo: “Mujo, what is a 'situation'?" Mujo: “Well, that's when you come back from work and you find me in bed with the neighbor's wife, that is a situation." Fata: "I see. So when you come back from work and you find me with 
the neighbor, that's also a situation?" Mujo: "No, woman, now you are mixing 'situation' with 'beating up'."

Here women are represented as dependent on men. A woman's agency is not only limited by her social relationship to a man through marriage, but in fact this social relationship resembles a material one (where a wife is compared to a bar) or slavery (where a man has proprietary powers over a woman's body). In the first example, a woman is objectified as a message, like the price of beer, employed in the communication between male subjects. In the second example, the man reserves the right to be polygamous while prohibiting the same right to his wife, under the threat of physical violence.

It is through humor that the gendered public/private distinction on which social identities rest is constituted, particularly in the former Yugoslavia where women are habitually considered to be "'womenfolk' who need men's protection" (Ramet 1999: 6). From a gender perspective, one can argue that jokes are an example par excellence of the structural violence of language: women are objectified and degraded as entirely dependent, stupid, frail, and sexually insatiable. Men, in relation to women as well as other men, are seen as aggressive, autonomous and, when compared to women, infinitely clever. The consequence of such jokes is a dual construction of femininity and masculinity.

Needless to say, jokes about sexes and about sexuality exist everywhere (Davies 2002: 3, 77-80). It is the profoundly gendered nature of jokes in particular that calls for action to deconstruct them and reveal the power relationships they create and sustain. The jokes examined in this paper can be said to serve the interests of men.[14]

Proposition 4. The war in Bosnia has no doubt had a momentous impact on Bosnian identity and also on popular jokes. In terms of art, the war has been approached on so many levels - from film to comic books - that it is difficult to plead ignorance. Some of these representations reflect on humor, which may be seen as typically Bosnian. For example, in No Man's Land (2001), a worn-out Bosnian frontline solider laments over a newspaper headline: "Ah, what a mess in Rwanda." The siege of Sarajevo in particular has assumed mythical proportions. Perhaps because of the unprecedented level of Western access and attention to the besieged city, Sarajevo has in fact turned into, according to a local author, a "brand name, like Benetton, Coca-Cola and Nike" (Kebo, as cited in Hicks 2002; see also Veličković 2003: 121). 
Sarajevo owes a large part of its fame to the fabled spirit of its besieged citizens, who have employed humor to defuse the tension (the "war humor" from Sarajevo has become in itself something of a brand name). Here is a selection:

Mujo is walking down the street, just out of the hospital after having his right arm amputated. He's depressed to the point of desperation, crying, talking to himself, thinking about suicide. He can't bear the thought of life without his arm. Suddenly he sees Suljo walking towards him, skipping and smiling. When he gets closer, Mujo sees that Suljo is actually laughing out loud. What is most amazing to Mujo is that Suljo is carrying on like this despite the fact that not just one, but both of his arms have been amputated. So Mujo stops Suljo, who continues to snicker and smile. Mujo says, "Suljo, I don't understand you. I'm desperate, I'm even thinking about killing myself, all because I've had one arm amputated. You've had both your arms cut off and here you are smiling and laughing like an idiot. In your condition, how can you be so happy?"

Suljo replies, "Mujo, if you'd had both of your arms cut off, like I did, and your ass was itching like crazy, you'd be laughing too" (trans. by Hicks, 2001).

Suljo sees his friend Mujo swinging back and forth on a child's swing set in the middle of Sarajevo's notorious 'Snipers' Alley.' Dodging from cover to cover, risking life and limb, Suljo finally gets close enough to shout, "Hey, Mujo, what the hell are you doing? Get out of there!"

Mujo shouts in reply, "I'm harassing the sniper!" (transl. from the Cultural Orientation website, Retrieved on March 30, 2003).

Cigarettes are in very short supply and Mujo had put his last one behind his ear (this part is usually excluded when the joke is told by Bosnians).

Mujo and Suljo are running over the Drvenija bridge when a sniper opens up on them. Mujo takes a hit which shears off his ear. He stops frantically in the middle of the bridge looking at the ground. Suljo yells, "Get under cover, idiot! You've got two ears!"

Mujo: "Fuck the ear, I am looking for the cigarette!"

Here, identities involving physical vulnerability and insecurity are apparent, and the jokes use a heavy dose of irony to highlight the predicament of how those lives are reduced to the siege and the war. The every-day tragedies of Mujo and Suljo can be both a "point of projection or catharsis for the fears and anxieties of others... people joke about only what is most serious" (Dundes 1987: iix).[15]

Of course, there are much more "sick" war jokes:

A fierce-looking četnik [Serb paramilitary] is going about his daily business of ethnically cleansing a Bosniak village. He stumbles over a frightened Bosniak child. "Hey, kiddo, how are you?" he asks him. The kid is terrified. "Hey, what 
are you are afraid of? Is it my long beard?" The kid stutters, very quietly: "No." "Is it my gun?" The kid: "Um, no." "Well, what is it then," asks the četnik, very curious at this point. The kid points to a very long knife, hanging from the četnik's belt. "Oh that," smiles the četnik, "Don't you worry, kid; I have a smaller one for you!"

A Serb, a Croat and a Bosnian talk sports. The Serb notes, "We are strong in the collective sports: basketball, volleyball, waterpolo..." The Croat says, "We are strong in the individual sports: tennis, skiing, karate..." The Bosnian, "We are strong in the sports for the disabled." The Serb and the Croat protest: "What do you mean "we"? But who was it who made them disabled in the first place?"

These two jokes are not made by Bosniaks. And if they are made by Serbs and Croats, they certainly contain no hint of self-reproach and remorse. But like the so-called Auschwitz jokes for postwar Germans, for Serbs, this war joke may be seen as a way of dealing with the guilt-ridden subject of ethnic cleansing and mass murder in Bosnia.

After exploring Auschwitz jokes and considering their reception, Dundes remains realistic: "In theory, telling jokes about Auschwitz might be a step toward acknowledging the reality of the death camps; but it may be nothing more than the same kind of bigotry that led to Auschwitz in the first place" (1987: 37). The difference, obviously, is enormous, and it cries for empirically based analyses.

Proposition 5. There is evidence to suggest that the war has brought about a change in the direction of Bosnian humor, and has also contributed to the proliferation of jokes about the enemies, Serbs and Croats, in which it is Bosnians who come out on top.

\footnotetext{
A Bosnian, a Serb and a Croat got drunk in Saudi Arabia. The locals report them to the police, and they are arrested. "Because you are foreigners and didn't know the laws, you will not be severely punished. Each one of you will get a beating consisting of 50 lashes on the back, but each will also be granted one wish with respect to the beating. The Bosnian gets two," proclaims a Saudi judge. The Croat says: "Before you start, I'd like you to tie a pillow to my back." After 5 lashes, the pillow hits the ground and the lashes continue. The Serb says: "Before you start, I'd like you to tie two pillows to my back." After 10 lashes, both pillows fall off and the lashes continue. The Bosnian says: "First, I'd like 100 hits instead of 50." The Saudis are taken aback a little but decide to wait for the second wish. "Second," the Bosnian says, "please tie the Serb tightly to my back."
}

The joke reveals a strong sense of hostility. Indicatively perhaps, for Bosniaks, Serbs appear to be a more menacing "other" than Croats. Here, the butt of the joke is canny or shrewd, which is another common type of joke (Davies 1990: 102).[16] In another example: 
Mujo and Suljo sit next to each other in the main square in Zagreb, the Croatian capital, and panhandle. Mujo: "I am an unemployed Croat veteran, please help me." Suljo: "I am an unemployed Serb veteran, please help me." Weeks pass, but only Mujo makes any money. One day, an older lady approaches, gives 10 kunas to Mujo and turns to Suljo: "Listen friend, why don't you go to Serbia and panhandle there. Obviously, here we will give only to our veteran." As soon as she leaves, Suljo snickers to Mujo: "Hm, like she knows what good marketing is."

Here, too, Mujo and Suljo are considered shrewd, even if they are still clearly poor and backward. These two jokes may be representative of an emerging body of Bosnian jokes in which others are systematically lampooned. Jokes come and go in cycles (Davies 1990: 131-170; Dundes 1987: vi). In the United States, the so-called Polack jokes have largely disappeared (Davies 1990, 2002; Dundes 1987), likely because other ethnicities are now used as the butt of American ethnic jokes.

In addition, stereotypes "may change over time, subject to the vagaries of historical events." (Dundes 1987: 122). For example, in the US, the Japanese are no longer seen as "sly, treacherous and sneaky" as they were in 1941 (ibid.). In terms of the argument of this paper, the idea of joke-cycles is a useful reminder that identities are bound in time and space and are subject to change. Identity must in fact be approached as a process, not as a static object in need of classification (Giddens 1984; Brubaker and Cooper 2000).

In Bosnia, the war, in which the Bosniaks turned out to be by far the greatest victims, can be said to have been an exogenous shock or a collective cognitive punch that changes self- and other-images. Perhaps the jokes in which Mujo, Suljo and Fata come out as stupid in front of their non-Bosnian neighbors are on the road to extinction. While one may be unable to gauge the intent of the joke-teller, any account of identity needs to consider the ways in which the dominant forms of identity are resisted. Like hegemonic discourses, the dominant joking relationships are proffered by those with greater access to social resources. Thus, because identity-formation is arguably a process of self- and otherdefinition intricately linked to the generation of threat perception (Wæver et al 1993, Buzan et al 1998), telling jokes which ridicule nonBosniaks can be seen as unconscious but popular resistance to dominant and threatening joking practices.

CONCLUSIONS 
Jokes have productive power - they constitute, reflect on, epitomize and reinforce ethnic, national, gendered and regional identities. This paper serves to confirm the assumption that identity is constituted in relation to difference (Connolly 2002, but see Weir 1998). The self, in other words, is constituted by the other. Also, I suggest that identity is produced and reproduced on a daily basis through narratives, which describe and inscribe social boundaries. Jokes are one of those "daily" narratives. But what makes jokes a powerful political tool is their embeddedness in popular culture. Through jokes, ideas and beliefs about the self and others can be transmitted to the lives of ordinary people. Complex social and political relationships can turn into simple and crude us-versus-them stories.

As I mentioned above, social identities that are both a product and a reflection of joking relationships are contingent and malleable. The cyclical and changing nature of intergroup humor suggests, however, that social identities, such as ethnicity and its derivative - nationalism, are rather fluid relationships (Duara 151, 163-4; Davies 1990: 8) and are, as such, contestable. This insight leads to the Foucauldian conclusion that there is no essential self outside discourse. Through telling, retelling and listening to jokes, social groups - able-bodied males, heterosexuals, Bosniaks, Herzegovinians - are discursively represented and constituted.

Because social identities do not exist outside discourse, they should not be treated as "facts" (Gillis 1994: 5). To borrow from another context:

Identities [and jokes] are not things we think about, but things we think with. As such they have no existence beyond our politics, our social relations, and our histories. We must take responsibility for their uses and abuses, recognizing that every assertion of identity involves a choice that affects not just ourselves but others. (ibid, emphasis in the original)

But when do jokes emerge? There is no doubt a definitive point in history before which jokes did not constitute the social identities explored in this paper. As I said above, Bosnian jokes and Bosnian identities after the war may greatly differ from Bosnian jokes and Bosnian identities before the war.

What about longer-term historical vistas? Davies, for one, is sceptical about the proposition that jokes are a pre-modern form and argues rather that jokes in which the object appears either stupid or canny are a product of modernity: 
It may be suggested that the dominance of these jokes in modern societies rather than jokes about other human qualities is related to the nature of modern societies with their emphasis on success and failure in a world that becomes ever more technically sophisticated and the subject of greater economic calculativeness (2002: 8).

Davies's point can perhaps be illustrated by the role technology (e.g. cell phones) plays in making the butt of a joke appear stupid. But because intergroup humor is essentially oral, I would conclude that it existed before the advent of print capitalism or, in my case, the Internet. In fact, I submit that most jokes have served to generate and sustain social identities and political self-awareness for ages. Just like Duara's folk tales in ancient China, intergroup jokes about stupidity in particular can be said to have served to differentiate one group from another on the basis culture and, therefore, ethnicity and nationhood (1996: 156, 163). Jokes arguably belong to that fuzzy narrative category which Alexander Motyl calls "orally transmitted myths":

Orally transmitted myths, such as epics, poems, and songs, are collective undertakings as much as they are the creations of a Homer or the preserve only of the actual storytellers. Their collective telling and retelling - and the listening to their telling and retelling - translate into a continual process of textual creation and recreation within which authors and readers are more or less equally implicated. (1999: 65)

Jokes qua myths can be said to establish basic continuities over time. This process includes the cultivation of ideas and beliefs about the self and others, as personified in the ideas and beliefs held by and about the protagonists in jokes.

From the above, I would also suggest that stories which constitute ethnic groups and nations are not just tales of common origins, continuity, heroism and martyrdom. They are also about characters such as Mujo, Suljo, and Fata. In other words, stories constitutive of nations need not originate in the intellectual sphere alone. At a minimum, I would suggest that the mass level of politics offers plenty of fertile ground for the manipulation of myths, which can then be used to make certain political outcomes more possible than others.

What I can say with far more aplomb is that intergroup humor is not an elite phenomenon, and that ethnic identity is constructed by elites and "ordinary people" alike. Thus, contrary to Anderson, Gellner, and Hobsbawm, the agency of elites should not be privileged with respect to the construction of ethnic and national identities. An assessment which 
suggests that nations, nationalisms, and nation-states are produced by intentional intellectual and political work needs more empirical bite, including, as I have argued, a more systematic look at humor.

Accordingly, then, let me end this paper with a discussion of possible avenues for such systematic research on the genesis and meaning of jokes. As I said, the purpose of this paper was to offer nothing more than a set of propositions. In order to find out why people tell particular kinds of jokes (e.g. why some jokes are self-depreciating), it would be prudent to compare stereotypes from jokes with those in other types of narratives, such as school textbooks, talk shows, soap operas, comedies and such.

More importantly, as Davies shows (2002: 4-8), one needs to link aggregate patterns of joking and stereotyping to the specific social circumstances about both the butt of the joke (the object, the "other") and the narrator (the subject, the self). Furthermore, the link will be valid only if the two bodies of evidence (jokes vs. social circumstances) are collected independently of each other (ibid.: 5, fn. 2). For example, one could attempt to link jokes about Bosnian sexuality to literary narratives. One of the most celebrated Bosnian authors, Meša Selimović,[17] identifies these "social circumstances":

I think that it was, aside from the influence of the Oriental sensibility, the historical situation of Bosnian Muslims that supported the development of psychic and emotional life. Guided primarily by religion for centuries, they have expressed, in the moments of relaxation, more passion in the personal, private sphere rather than in public and national endeavours... But it is wrong to understand [the private sphere] as a solely erotic one; this is, in fact, the subordinated emotional sphere, the greatest manifestation of which are [Bosnian] Muslim national ballads. Because of the lack of other social and collective aspirations, I think that this was a retreat into the only remaining free realm, a psychological and emotional refuge. $(34-5, \mathrm{fn} .1)$

I would argue that this and similar insights are reflected in several of Selimović's novels. Of course, examples such as this one are mere speculations. The point is that the above propositions (and their theoretical implications) mean little unless they are accompanied with an empirical analysis that matches two sets of aggregates - collections of jokes and data on social and historical contexts. This would no doubt be a mammoth task. But if such deep empirical research is not carried out, one simply cannot produce valid, reliable and falsifiable explanations about social phenomena. 
Comparison can and should be historical as well. As I said, some forms of joking may be on the way out from the discursive spaces in and around Bosnia. One way to chart changes in joking practices would be to collect those jokes which are "datable" - those which have a direct reference to, say, the history of the recent war, and to ask whether those jokes differ in kind from pre-war jokes. If identities are determined by changes in historical circumstances, then the critical question is how they change, and when, and what that change can tell us about society and politics.

Can a study of discursive representations help us understand action and interaction in politics? I suggested that a study of joking relationships reveals intersubjective webs of meaning. Similarly, jokes can be studied as cognitive phenomena. Psychologists have long argued that one must take into account the role of ideas and beliefs before one can predict how political actors perceive the world and how they interact (Gardener 1985). Following the work of Herrmann and Fischerkeller (1995), for instance, one could look at jokes and other narratives in the former Yugoslavia with the aim of analyzing the patterns of ethnic conflict and cooperation. Such research would first distil dominant images actors hold about each other; second, it would link them to policy options and, third, it would situate these links in, say, a game-theoretic framework and theorize about possible conflict and cooperation outcomes. In any event, it seems that "identifying what the prevailing images are is a necessary first step in any further causal regression" (1995: 449). And as similar research strategies could be employed to look at other kinds of intergroup relationships, one can then conclude that a compilation of a Sarajevo Joke Book should be seen as a gravely serious project for both the humanities and the social sciences.

\section{NOTES}

[1] I thank Ted Hopf and Jutta Weldes for their helpful comments and criticisms on an earlier draft of this essay as well as to three anonymous reviewers. I am also grateful to the participants of the Sixth International Seminar "Democracy and Human Rights in Multiethnic Societies," Konjic, Bosnia, July 7-11, 2003. These individuals bear no responsibility whatsoever for any errors and/or shortcomings in this paper. 
[2] Tajfel's definition of social identity is no worse than others and better than many: “[...] that part of the individual's self-concept which derives from his knowledge of his membership of a social group (or groups) together with the value and emotional significance attached to that membership" (1981: 255). In-group membership is obviously important: because they live in an otherwise chaotic world, individuals require the support of their groups - in terms of the provision of a frame of reference - in order to make everyday judgments and decisions (Berger and Luckmann 1966).

[3] Attitudes, such as prejudice, have cognitive (belief-based) and conative (behavior-oriented) components (Jackman 1977). For instance, the belief that immigrants take jobs and/or are responsible for crime leads to voting for right-wing populist parties (Betz 1994: 4). Obviously, one can make several connections between humor and behavior, provided that one controls for the political, economic, historical and other relevant dimensions. Nevertheless, an exploration of stereotypical images in Bosnia and, say, their impact on judgment and decision-making among a given set of social groups is clearly beyond the scope of this paper.

[4] For a discussion of issues of reliability in Internet-based research, see Smith (1997). My primary database was collected through unstructured direct observation, that is, jokes were observed as they happened in direct contact with subjects and then afterwards recorded in "field notes." Unlike folklorists like Dundes, political scientists like myself are instructed to frown upon direct observation because of its low level of reliability and (external) validity (i.e. the data collected is contaminated by the observer's bias). While I believe that all data are subjective, I have tried to be an unobtrusive observer in order to eliminate the possibility of subjects altering their behavior (telling and responding to jokes) because they were being studied, which, we are told, is likely to produce more valid information. I am aware of various ethical conundrums that revolve around unobtrusive observation. I use quotation marks for "fieldwork" and "field notes" because I am not quite sure when my "scientific" work began - indeed, I have participated in telling, retelling, and listening to Bosnian (and other) jokes and thus collecting them since I can remember.

[5] A social ontology which accepts the contestability, malleability, and interdependence of social groups is probably a way out of such reification. See Weir (1998), esp. the chapter on Kristeva and the 
conclusion. In the meantime, in Bosnia, like elsewhere, we may rely on the laws against verbal harassment (Čengić 2003).

[6] For a discussion and definition of these terms, see Ramet (1996). On Bosniaks, also see Hamourtziadou (2002). On a separate note, Serbian anxiety regarding Bosniaks has been particularly salient. Research on elementary school textbooks dealing with Serbia's international relations shows that the Ottomans/Turks are considered to be the greatest Serbian enemy (Pešić and Rosandić 1994). This 'historical enmity' towards the Ottomans/Turks is habitually transposed onto the Bosniaks - which was obviously mobilized to play a key role in the ethnic cleansing campaigns in the 1990s - and results in a systematic denial of the existence of a distinct Bosniak ethnic and national identity, even among some liberal intellectuals. And while there is a shortage of recent survey research on this topic, it is generally accepted that many Serbs have not come to terms with the existence of a separate Bosniak nation or the Bosnian language.

[7] Any study of intergroup humor needs to differentiate between the socalled culture-specific and generalized, slot-filler jokes (Dundes 1987: 100). The Bosnian war jokes examined below can be seen as culturally specific. For most of the others, however, there is no sure way of determining their cultural specificity. In fact, many jokes easily transcend time and space. For example, jokes involving pantomime can have uniform effects in very different contexts (e.g. the silent movies of Charlie Chaplin and Buster Keaton evoke laughter even today).

[8] There are several other patterns: Bosnians, Slovenes, Croats, Serbs and Montenegrins tell jokes about each other; Macedonians are not prominent; Serbs and, to a lesser extent, Croats and Bosnians tell jokes about Albanians; all of these groups tell jokes about the Roma, Jews, Russians, Germans, English, French, Americans and, to a lesser extent, black Africans, Chinese and Japanese. As for the intramural regional patterns, Croats from Croatia tell jokes about Croats from Hercegovina, Bosnians of all stripes tell jokes about Herzegovinians of all stripes. Serbs from central Serbia tell jokes about Vojvodinians and vice versa, etc. Most of these (and other) communities, also have their intramural jokes.

[9] I could add that similar 'nesting' often surfaces in journalistic and pseudoacademic reflections on the dissolution of Yugoslavia. A National Geographic (August 1990) report on the onset of Yugoslav drama, 
particularly its photo story, is one of the more glaring examples of such 'gradation' of Orientalisms.

[10] In a spin on the Orientalist theme involving intergroup humor, there is a host of jokes that ridicule how the Bosnian language uses bastardised Turkish and other foreign words to describe modern phenomena: a police officer is said to be called pendrek-efendija (baton mister) and maksuz pendrek-efendija (for special police: big time baton mister). An army tank is called belaj-bager (troubleplower) and a female figure skater is called zork-hanuma (twistwoman). Again, these jokes are supposed to reflect the inferiority of Bosnians as compared to the other groups and to show how Bosnia is a provincial country.

[11] A recent survey conducted in Bosnia shows that Bosnians of all ethnicities agree that Roma are the least desirable neighbor, marriage partner, or extended family member (Puhalo 2003).

[12] I am grateful to Redžep Misimović for this insight.

[13] The vocabulary and intonation of jokes is not the same in, say, Sarajevo (where vowels are swallowed) and Mostar (where vowels are long). Language may be the key to determining the identity of the narrator and the butt (Davies 1990: 50-63).

[14] Again, I am talking about able-bodied, heterosexual men. The jokes reveal not only misogyny but also homophobia. A joke: "Dad, I think I have a crush." "Great son! On whom?" "On Jovica." [Serbian male name] "But he is a Serb, son!" Here the point of the joke is in the fact that a romantic relationship with a member of an ethnic "other" is portrayed to be more alarming than homosexuality. For an excellent discussion of homophobia in contemporary Croatia and the former Yugoslavia more generally, see Pavlović. On gender politics in the region in general, see Zarkov and the collection edited by Ramet (1999).

[15] But not all jokes serve as a sudden relief from anxiety and tension. Milgram (1963), in one of his terrifying experiments, found that laughter can also elevate tension.

[16] It is commonly assumed that intergroup humor reflects the patterns of intergroup hostility (Nevo 1984). Davies, however, points out that "conflict and hostility are neither a necessary nor a sufficient condition for the generation of jokes about stupidity" (2002: 11). The main butt of stupidity-based jokes in Syria is not Jews, Turks, Iraqis or Westerners - which would reflect the patterns of conflict and 
hostility - but citizens of Homs, a peripheral but an intramural community (ibid.).

[17] Selimović can be regarded as another exemplar of Bosnia's "confused identities". His writings are extremely rich in identity-talk (see, e.g., 1986: 19-23).

\section{B I B L I O G R A P H Y}

Anderson, Benedict. Imagined Communities: Reflections on the Origin and Spread of Nationalism. New York: Verso, 1991.

Apte, Mahadev L. Humor and Laughter: An Anthropological Approach. Ithaca, N.Y.: Cornell University Press, 1985.

Bakić-Hayden, M. "Nesting Orientalism. The Case of Former Yugoslavia." Slavic Review 54.4 (1995).

Berger, Peter and Thomas Luckmann. The Social Construction of Reality. New York: Doubleday, 1966.

Betz, Hans-Georg. Radical Right-Wing Populism in Western Europe. New York: St. Martins Press, 1994.

Bose, Sumantra. Bosnia After Dayton: Nationalist Partition and International Intervention. London: Oxford University Press, 2002.

Brandt, Charles S. “On Joking Relationships." American Anthropologist 50 (1948): 160-2.

Brubaker, Roger and Frederick Cooper. "Beyond 'Identity.'” Theory and Society 29 (2000): 1-47.

Buzan, Barry et al. Security: A New Framework for Analysis. Boulder, Co: Lynne Rienner Publishers, 1998.

Connolly, William E. Identity/difference: Democratic Negotiations of Political Paradox. Minneapolis: University of Minnesota Press, 2002.

Čengić, R. "Kazne i za pričanje viceva o plavušama." Nezavisne novine August 18, 2003.

Danforth, Kenneth C. "Yugoslavia: A House Much Divided." National Geographic 1782 (August 1990): 92-123.

Davies, Christie. Ethnic Humor around the World: a Comparative Analysis. Bloomington, Ind.: Indiana University Press, 1990.

. The Mirth of Nations. New Brunswick, NJ: Transaction Publishers, 2002.

Duara, Prasenjit. "Historicizing National Identity, or Who Imagines What and When." Geoff Eley and Ronald Grigor Suny, eds. Becoming National. Oxford: Oxford University Press, 1996. 151-77.

Dundes, Alan. Cracking Jokes: Studies of Sick Humor Cycles E Stereotypes. Berkeley, Calif.: Ten Speed Press, 1987. 
Ehrlich, Howard J. "Observations on Ethnic and Intergroup Humor." Ethnicity 6 (1979).

Gardener, Howard. The Mind's New Science: A History of Cognitive Revolution. New York: Basic Books, 1985.

Gellner, Ernest. Nations and Nationalism. Oxford: Blackwell, 1983.

Giddens, A. Modernity and Self Identity. London: Polity Press, 1991. The Constitution of Society. Berkley: University of California Press, 1984.

Gillis, John. "Memory and Identity: The History of a Relationship." Gillis, ed. Commemorations: the Politics of National Identity. Princeton: Princeton University Press, 1994.

Hamourtziadou, Lily. "The Bosniaks: from Nation to Threat." Journal of Southern Europe and the Balkans 4.2 (2002): 141-57.

Herrmann, Richard K. and Michael P. Fischerkeller. "Beyond the Enemy Image and Spiral Model: Cognitive-Strategic Research After the Cold War." International Organization 49.3 (1995): 415-50.

Hicks, Jim. "'What's It Like There?': Desultory Notes on the Representation of Sarajevo," Postmodern Culture 12: 2 (2002), http://www.iath.virginia.edu/pmc/textonly/issue.102/12.2hicks.txt [Retrieved on March 2, 2003]

Hobsbawm Eric and Terence Ranger, eds. The Invention of Tradition. New York: Cambridge University Press, 1983.

Jackman, Mary. "Prejudice, Tolerance, and Attitudes toward Ethnic Groups." Social Science Research 6 (1977): 145-69.

Kebo, Ozren. Sarajevo za početnike. Sarajevo: Dani, 1999.

Lovrenović, Ivan and Francis R. Jones. Life at the Crossroads. Sarajevo: Forum Bosnæ, 2001.

Milgram, Stanley. "Behavioural Study of Obedience." Journal of Abnormal and Social Psychology 67.3 (1963): 371-8.

Motyl, Alexander. "Inventing Invention: The Limits of National Identity Foundation." Ronald Grigor Suny and Michael Kennedy, eds. Intellectuals and the Articulation of the Nation. Michigan: Michigan University Press, 1999.

Nevo, Ofra. "Appreciation and Production of Humor as an Expression of Aggression: A Study of Jews and Arabs in Israel." Journal of CrossCultural Psychology 15.1 (1984): 181-98.

Nielsen, Don L.F. Humor Scholarship: A Research Bibliography. Westport, Conn: Greenwood Press, 1993.

Pavlović, Tatjana. "Women in Croatia: Feminists, Nationalists and Homosexuals." Ramet, ed. Gender Politics in the Western Balkans. University Park, PA: Penn State University Press, 1999. 131-53. 
Pešić, Vesna and Ružica Rosandić, eds. Warfare, Patriotism, and Patriarchy: An Analysis of Elementary School Textbooks. Belgrade: Center for Antiwar Action, 1994.

Puhalo, Srdjan. "Bratstvo mržnje i jedinstivo turizma." Dani 304, April 11, 2003.

Ramet, Sabrina Petra. "Introduction." Ramet (ed.) Gender Politics in the Western Balkans. University Park, PA: Penn State University Press, 1999. 3-11.

"Primordial Ethnicity or Modern Nationalism: The Case of Yugoslavia's Muslims, Reconsidered." Andreas Kappeler et al, eds. Muslim Communities Reemerge: Historical Perspectives on Nationality, Politics, and Opposition in the Former Soviet Union and Yugoslavia. Durham, NC: Duke University Press, 1994. 111-40.

Ross, Lee and Richard E. Nisbett. The Person and the Situation: Perspectives of Social Psychology. New York: McGraw-Hill, 1991.

Said, Edward. Orientalism. New York: Vintage, 1979.

Selimović, Meša. Sjećanja: memoarska proza. Beograd: BIGZ, 1986.

Smith, Alastair G. "Testing the Surf: Criteria for Evaluating Internet Information Resources," The Public-Access Computer Systems Review 8: 3 (1997), http://info.lib.uh.edu/pr/v8/n3/smit8n3.html [Retrieved on April 12, 2003]

Spivak, Gayatri, ed. The Post-Colonial Critic: Interviews, Strategies, Dialogues. New York: Routledge, 1990.

Tajfel, Henri. Human Groups and Social Categories. Cambridge: Cambridge University Press, 1981.

Todorova, Maria. “The Balkans: From Discovery to Invention." Slavic Review 53.2 (1994): 450-78.

Veličković, Nenad. Konačari. Sarajevo: OKO, 2003.

Weir, Allison. Sacrificial Logics. Feminist Theory and the Critique of Identity. New York: Routledge, 1996.

Wæver, Ole at al. Identity, Migration and the New Security Agenda in Europe. London: Routledge, 1993.

Wolff, Larry. Inventing Eastern Europe. Stanford: Stanford University Press, 1994.

Žarkov, Dubravka. "Gender, Orientalism and the History of Ethnic Hatred in the Former Yugoslavia." Helma Lutz, Ann Pheonix and Nira Yuval Davis, eds. Crossfires: Nationalism, Racism and Gender in Europe. London: Pluto Press, 1995. 